\title{
PITRM1 wt Allele
}

National Cancer Institute

\section{Source}

National Cancer Institute. PIT RM1 wt Allele. NCI Thesaurus. Code C131238.

Human PIT RM1 wild-type allele is located in the vicinity of 10p15.2 and is approximately $35 \mathrm{~kb}$ in length. This allele, which encodes presequence protease, mitochondrial protein, plays a role in peptide degradation. 